\title{
AMPLIFICATION FACTORS IN THE CASE OF BEAM UNDER MOVING FORCE - THEORETICAL ANALYSIS
}

\begin{abstract}
M. ATAMAN ${ }^{1}$
The impact of a moving load speed on the dynamic overload of beams, assuming that the track of the load has no unevenness, is examined. First the problem of a visco-elastic beam on a Winkler foundation subjected to a force moving at a constant speed will be solved. Using the Bubnov-Galerkin method, the deflections of the beam, and then the bending moments and shear forces will be determined. The solution of the problem will be obtained both for the case of a forced vibration and the case of a free vibration after the moving force has left the beam. Using these solutions, dynamic amplification factors will be determined for the deflections, bending moments, and shear forces, which are different for the two cases.

The magnitude of the amplification factors increases and decreases alternately as a function of the speed. In the case of a single force on a beam, the dynamic overloads are limited, and do not exceed $60 \%$. There is no resonance phenomenon in the beam subjected to the single moving force. The dynamic amplification factors determined in this way can be used as correction coefficients when designing engineering structures subjected to moving loads by static methods.
\end{abstract}

Keywords: vibrations of beams, Winkler foundation, moving load, damping, dynamic amplification factor

\section{INTRODUCTION}

One of the factors affecting the vibration of beams and slabs in bridge structures and road pavements is the speed of the vehicles. Because in engineering practice often structures are designed using static solutions with a subsequent application of dynamic amplification factors, the proper determination of these factors is of great importance. Besides the speed of the vehicles, there are a number of factors that have an impact on the magnitudes of the dynamic factors, such as the length of the span and its support, the condition of the structure, the pavement's unevenness, etc., which have been the subject of many analyses, e.g. $[3,4,8,12,14]$. A review of analytical and

\footnotetext{
${ }^{1}$ PhD., Eng., Warsaw University of Technology, Faculty of Civil Engineering, Al. Armii Ludowej16, 00-637 Warsaw, Poland, e-mail: m.ataman@il.pw.edu.pl
} 
experimental methods for the determination of the dynamic coefficients in road bridges can be found in [9].

The concept of dynamic coefficient appeared in the second half of the nineteenth century when designing railway bridges. Most of the standards for the design of engineering structures subjected to moving loads still introduce this coefficient. In the AASHTO [1] specifications, the impact factor depends on the length of the span of the bridge as follows:

$$
I M=\frac{50}{L+125}
$$

where

$L$ is the length of a single span measured in feet.

In the European standard [10] the dynamic factor in a railway bridge depends on the quality of the track maintenance and is given by the formulas

$$
\Phi_{2}=\frac{1.44}{\sqrt{L_{\Phi}}-0.2}+0.82 \text {, and } \Phi_{3}=\frac{2.16}{\sqrt{L_{\Phi}}-0.2}+0.73 \text {, }
$$

where

$L_{\Phi}$ is the determinant length.

The standards in force in Poland along with the dynamic factors for bridges are discussed, e.g. in [7] and [17]. The study [11] presents a number of formulas for dynamic factors proposed by different researchers and technical organizations.

Among the scientific studies devoted to this problem, one should also mention Fryba [5], Yang et al. [15] and paper [14], Galdos [6], Paulter [9], Zhang [16], and others.

In the literature, various definitions of dynamic factor can be found. Usually this factor is defined in two ways:

$$
n_{d}=\frac{R_{d}(x)}{R_{s}(x)}, \quad \text { or } \quad n_{d}=\frac{R_{d}(x)-R_{s}(x)}{R_{s}(x)},
$$

where 
$R_{d}$ is the maximum dynamic response and $R_{s}$ is the maximum static response.

In this paper, the impact of vehicle speed on the magnitude of the dynamic factors, determined by (1.3), will be analysed, assuming that the surface is without roughness.

The effect of a moving load on the vibrations of the road and railway pavement as well as on road and rail bridges will be presented by solving the problem of a simply supported beam resting on a deformable foundation, loaded with a force moving at a constant speed.

The dynamic coefficients in the case of deflections, bending moments and shear forces will be determined. In the analysis, we will take into account both forced vibrations as well as free vibrations when the load is already outside the beam.

\section{DAMPED VIBRATIONS OF A BEAM UNDER A MOVING FORCE}

Consider a simply supported beam resting on a deformable foundation, taking into account mass damping and construction damping. The equation of motion of such a beam subjected to the force $P$ moving at velocity $v$ is

$$
E J \frac{\partial^{4} w}{\partial x^{4}}+c_{i} J \frac{\partial^{5} w}{\partial t \partial x^{4}}+m \frac{\partial^{2} w}{\partial t^{2}}+c_{e} \frac{\partial w}{\partial t}+k w=P \delta(x-v t), \quad 0 \leq v t \leq l
$$

in which

$w$ is the deflection of the beam, $E J$ is the flexural stiffness of the beam, $m$ is the mass of a one-meter long beam, $c_{i}$ and $c_{e}$ are the damping coefficients of the beam material, $k$ is the coefficient of the elastic Winkler foundation,. and $l$ is the length of the beam.

This problem will be solved by the Bubnov-Galerkin method. The deflection of the beam due to the $n$-th mode of vibration is assumed to have the form $w(x, t)=\varphi_{n}(x) q_{n}(t)$, where $\varphi_{n}(x)$ denotes the $n$-th form of natural vibration of the beam, fulfilling boundary conditions, and $q_{n}(t)$ denotes the generalised coordinate corresponding to the $n$-th mode of the natural vibrations of the beam. We assume there is a proportionality of damping coefficient $c_{e}$ to the mass of the beam $m$, and of the damping coefficient $c_{i}$ to the Young's modulus $E$ and define the equivalent damping number $\xi_{n}$ by 


$$
c_{e}=\alpha_{e} m, \quad c_{i}=\alpha_{i} E, \quad \xi_{n}=\frac{1}{2}\left(\frac{\alpha_{e}}{\omega_{n}}+\alpha_{i} \omega_{n}\right) .
$$

After taking into account the formulas (2.2), we may write the equation for the generalised coordinate in a known form:

$$
\ddot{q}_{n}+2 \xi_{n} \omega_{n} \dot{q}_{n}+\omega_{n}^{2} q_{n}=\frac{P \int_{0}^{l} \varphi_{n}(x) \delta(x-v t) d x}{\int_{0}^{l} m\left[\varphi_{n}(x)\right]^{2} d x},
$$

where

$\omega_{n}$ is the natural frequency of the beam, given by formula (2.4)

$$
\omega_{n}=\sqrt{\frac{E J \int_{0}^{l} \varphi_{n}^{4}(x) \varphi_{n}(x) d x}{m \int_{0}^{l}\left[\varphi_{n}(x)\right]^{2} d x}+\frac{k}{m}} .
$$

The detailed derivation of the equation (2.3) can be found in the paper [2].

As results from (2.4), the circular frequency of the beam on a Winkler foundation is always greater than the frequency of the beam not resting on the foundation.

Equation (2.3) is valid only in the case when the force is on the beam, that is, $0 \leq v t \leq l$.

In the case of a simply supported beam, the $n$-th eigenfunction is defined by a sinusoid

$$
\varphi_{n}(x)=\sin (n \pi x / l),
$$

and equation (2.3) reduces to the form

$$
\ddot{q}_{n}+2 \xi_{n} \omega_{n} \dot{q}_{n}+\omega_{n}^{2} q_{n}=\frac{2 P}{m l} \sin \frac{n \pi v t}{l},
$$

where 
$\omega_{n}=\sqrt{\frac{n^{4} \pi^{4}}{l^{4}} \frac{E J}{m}+\frac{k}{m}}$ denotes the natural frequency of a simply supported beam resting on the Winkler foundation.

After solving the equation of motion (2.6) and taking into account (2.5), the deflection of the beam is

$$
\begin{aligned}
w(x, t) & =\frac{2 P l^{3}}{\pi^{4} E J} \sum_{n=1}^{\infty} \frac{1}{n^{4}\left[\left(1-S_{n}^{2}\right)^{2}+4\left(\xi_{n} S_{n}\right)^{2}\right]}\left\{\left(1-S_{n}^{2}\right) \sin \beta_{n} t-2 \xi_{n} S_{n} \cos \beta_{n} t+\right. \\
& \left.+e^{-\xi_{n} \omega_{n} t}\left[2 \xi_{n} S_{n} \cos \tilde{\omega}_{n} t+\frac{S_{n}}{\sqrt{1-\xi_{n}^{2}}}\left(2 \xi_{n}^{2}+S_{n}^{2}-1\right) \sin \tilde{\omega}_{n} t\right]\right\} \sin \frac{n \pi x}{l},
\end{aligned}
$$

where

$\tilde{\omega}_{n}=\omega_{n} \sqrt{1-\xi_{n}^{2}}$ is the circular frequency of damped free vibration of the beam,

$\beta_{n}=\frac{n \pi v}{l}$ is the equivalent frequency of the vibrations forced by the moving force,

$S_{n}=\frac{\beta_{n}}{\omega_{n}}=\frac{n \pi v}{\omega_{n} l}$ is the dimensionless parameter of the velocity of the moving force.

The components in the above solution with the argument $\beta_{n} t$ determine the purely forced damped vibrations, while the components with the argument $\tilde{\omega}_{n} t$ determine the free damped vibrations.

For a visco-elastic beam resting on a Winkler foundation, the dynamic bending moment $M_{\alpha}(x, t)$ and the dynamic shear force $T_{\alpha}(x, t)$ are determined using (2.7) and by the definitions

$$
\begin{aligned}
& M_{\alpha}(x, t)=-E J \frac{\partial^{2} w(x, t)}{\partial x^{2}}-c_{i} J \frac{\partial^{3} w(x, t)}{\partial x^{2} \partial t}, \\
& T_{\alpha}(x, t)=-E J \frac{\partial^{3} w(x, t)}{\partial x^{3}}-c_{i} J \frac{\partial^{4} w(x, t)}{\partial x^{3} \partial t},
\end{aligned}
$$

which yields 


$$
\begin{aligned}
& M_{\alpha}(x, t)= \frac{2 P l}{\pi^{2}} \sum_{n=1}^{\infty} \frac{1}{n^{2}\left[\left(1-S_{n}^{2}\right)^{2}+4\left(\xi_{n} S_{n}\right)^{2}\right]}\left\langle\left\{\left(1-S_{n}^{2}\right) \sin \beta_{n} t-2 \xi_{n} S_{n} \cos \beta_{n} t+\right.\right. \\
&\left.+e^{-\xi_{n} \omega_{n} t}\left[2 \xi_{n} S_{n} \cos \tilde{\omega}_{n} t+\frac{S_{n}}{\sqrt{1-\xi_{n}^{2}}}\left(2 \xi_{n}^{2}+S_{n}^{2}-1\right) \sin \tilde{\omega}_{n} t\right]\right\}+ \\
&+\frac{c_{i}}{E}\left\{\beta_{n}\left(1-S_{n}^{2}\right) \cos \beta_{n} t+2 \xi_{n} S_{n} \beta_{n} \sin \beta_{n} t+\right. \\
&-\xi_{n} \omega_{n} e^{-\xi_{n} \omega_{n} t}\left[2 \xi_{n} S_{n} \cos \tilde{\omega}_{n} t+\frac{S_{n}}{\sqrt{1-\xi_{n}^{2}}}\left(2 \xi_{n}^{2}+S_{n}^{2}-1\right) \sin \tilde{\omega}_{n} t\right]+ \\
&\left.+e^{-\xi_{n} \omega_{n} t}\left[-2 \xi_{n} \tilde{\omega}_{n} S_{n} \sin \tilde{\omega}_{n} t+\frac{S_{n} \tilde{\omega}_{n}}{\sqrt{1-\xi_{n}^{2}}}\left(2 \xi_{n}^{2}+S_{n}^{2}-1\right) \cos \tilde{\omega}_{n} t\right]\right\} \sin \frac{n \pi x}{l},
\end{aligned}
$$

(2.9)

$$
\begin{aligned}
& T_{\alpha}(x, t)= \frac{2 P}{\pi} \sum_{n=1}^{\infty} \frac{1}{n\left[\left(1-S_{n}^{2}\right)^{2}+4\left(\xi_{n} S_{n}\right)^{2}\right]}\left\langle\left\{\left(1-S_{n}^{2}\right) \sin \beta_{n} t-2 \xi_{n} S_{n} \cos \beta_{n} t+\right.\right. \\
&+\left.e^{-\xi_{n} \omega_{n} t}\left[2 \xi_{n} S_{n} \cos \tilde{\omega}_{n} t+\frac{S_{n}}{\sqrt{1-\xi_{n}^{2}}}\left(2 \xi_{n}^{2}+S_{n}^{2}-1\right) \sin \tilde{\omega}_{n} t\right]\right\}+ \\
&+\frac{n \pi c_{i}}{E l}\left\{\beta_{n}\left(1-S_{n}^{2}\right) \cos \beta_{n} t+2 \xi_{n} S_{n} \beta_{n} \sin \beta_{n} t+\right. \\
&- \xi_{n} \omega_{n} e^{-\xi_{n} \omega_{n} t}\left[2 \xi_{n} S_{n} \cos \tilde{\omega}_{n} t+\frac{S_{n}}{\sqrt{1-\xi_{n}^{2}}}\left(2 \xi_{n}^{2}+S_{n}^{2}-1\right) \sin \tilde{\omega}_{n} t\right]+ \\
&\left.\left.+e^{-\xi_{n} \omega_{n} t}\left[-2 \xi_{n} \tilde{\omega}_{n} S_{n} \sin \tilde{\omega}_{n} t+\frac{S_{n} \tilde{\omega}_{n}}{\sqrt{1-\xi_{n}^{2}}}\left(2 \xi_{n}^{2}+S_{n}^{2}-1\right) \cos \tilde{\omega}_{n} t\right]\right\}\right) \cos \frac{n \pi x}{l} .
\end{aligned}
$$

Solutions (2.7) and (2.9) are simplified if damping neglected, $\xi_{n}=0$ :

$$
\begin{aligned}
& w(x, t)=\frac{2 P l^{3}}{\pi^{4} E J} \sum_{n=1}^{\infty} \frac{1}{n^{4}}\left(\frac{\sin \beta_{n} t-S_{n} \sin \omega_{n} t}{1-S_{n}^{2}}\right) \sin \frac{n \pi x}{l}, \\
& M_{\alpha}(x, t)=\frac{2 P l}{\pi^{2}} \sum_{n=1}^{\infty} \frac{1}{n^{2}}\left(\frac{\sin \beta_{n} t-S_{n} \sin \omega_{n} t}{1-S_{n}^{2}}\right) \sin \frac{n \pi x}{l}, \\
& T_{\alpha}(x, t)=\frac{2 P}{\pi} \sum_{n=1}^{\infty} \frac{1}{n}\left(\frac{\sin \beta_{n} t-S_{n} \sin \omega_{n} t}{1-S_{n}^{2}}\right) \cos \frac{n \pi x}{l} .
\end{aligned}
$$


Solutions (2.7), (2.9) and (2.10) are valid if a force is applied to the beam, i.e. for $v t \leq l$. After the load leaves the beam $v t>l$, we have a free damped vibration of the beam or with free vibration if damping is neglected. The equation of motion of the beam (2.3) or (2.6) becomes then homogeneous with the new initial conditions resulting from solving (2.3) or (2.6) at time $t=l / v$. The free damped vibrations, respectively, free undamped vibrations, of the beam are described in this case by

$$
\ddot{\tilde{q}}_{n}+2 \xi_{n} \omega_{n} \dot{\tilde{q}}_{n}+\omega_{n}^{2} \tilde{q}_{n}=0, \quad \ddot{\hat{q}}_{n}+\omega_{n}^{2} \hat{q}_{n}=0 .
$$

After solving (2.11), we obtain the beam deflections in the case of free damped, respectively undamped vibrations:

$$
\begin{gathered}
\tilde{w}(x, t)=\sum_{n=1}^{\infty} e^{-\omega_{n} \xi t}\left(A \cos \tilde{\omega}_{n} t+B \sin \tilde{\omega}_{n} t\right) \sin \frac{n \pi x}{l}, \\
\hat{w}(x, t)=\sum_{n=1}^{\infty}\left(A_{1} \cos \omega_{n} t+B_{1} \sin \omega_{n} t\right) \sin \frac{n \pi x}{l} .
\end{gathered}
$$

The constants of integration $A, B$ and $A_{1}, B_{1}$ should be determined from the initial conditions at time $t=l / v$, i.e. when the moving force leaves the beam. In the case of the analysis of the vibration of the midpoint of the beam, these conditions are

$$
\begin{array}{ll}
q\left(\frac{l}{2}, \frac{l}{v}\right)=\tilde{q}\left(\frac{l}{2}, \frac{l}{v}\right), & \frac{\partial q\left(\frac{l}{2}, \frac{l}{v}\right)}{\partial t}=\frac{\partial \tilde{q}\left(\frac{l}{2}, \frac{l}{v}\right)}{\partial t}, \\
q\left(\frac{l}{2}, \frac{l}{v}\right)=\hat{q}\left(\frac{l}{2}, \frac{l}{v}\right), & \frac{\partial q\left(\frac{l}{2}, \frac{l}{v}\right)}{\partial t}=\frac{\partial \hat{q}\left(\frac{l}{2}, \frac{l}{v}\right)}{\partial t} .
\end{array}
$$

Due to the complicated form of the constants of integration, we will not present the expressions describing these constants and definitive formulas for the beam deflections. In the case of free vibrations, when $v t>l$, the dynamic bending moment and the dynamic shear force can be calculated using definition (2.8) and the deflections determined from (2.12).

The results of the analytical solution of the problem of a moving force on a visco-elastic beam will be presented graphically in Section 4 . 


\section{DYNAMIC FACTORS FOR A SIMPLY SUPPORTED BEAM UNDER}

\section{A MOVING LOAD}

The effect of a moving load on the magnitude of the impact factors will be presented for the example of a simply supported beam subjected to a force moving at a constant velocity. We will determine the dynamic factors for the deflections, bending moments and shear forces. We will analyse forced vibrations, as well as free vibrations, when the position of the moving load is outside the beam. Internal and external damping will be taken into account. In the case of undamped vibrations of a simply supported beam, without consideration of the foundation, the second definition (1.3) and the first formula of (2.9) lead to the following expression for the impact factor for the midpoint deflection:

$$
\begin{gathered}
w_{s t}\left(\frac{l}{2}\right)=\frac{P l^{3}}{48 E J}=\frac{2 P l^{3}}{E J \pi^{4}} \sum_{n=1}^{\infty} \frac{1}{n^{4}} \sin ^{2} \frac{n \pi}{2}, \quad \omega_{n}=\frac{n \pi v}{S_{n} l}=\frac{\beta_{n}}{S_{n}}, \\
n_{d}^{w}=\frac{96}{\pi^{4}} \sum_{n=1}^{\infty} \frac{1}{n^{4}}\left(\frac{\sin \beta_{n} t-S_{n} \sin \omega_{n} t}{1-S_{n}^{2}}\right) \sin \frac{n \pi}{2}-1 .
\end{gathered}
$$

Similarly, the dynamic factor for the midpoint bending moment of the beam can be written

$$
n_{d}^{M}=\frac{8}{\pi^{2}} \sum_{n=1}^{\infty} \frac{1}{n^{2}}\left(\frac{\sin \beta_{n} t-S_{n} \sin \omega_{n} t}{1-S_{n}^{2}}\right) \sin \frac{n \pi}{2}-1
$$

The shear dynamic factor is determined when the load is at a point on the left or the right support, i.e. for $x=0$ or $x=l$

$$
n_{d}^{T}=\frac{2}{\pi} \sum_{n=1}^{\infty} \frac{1}{n} \cos n \pi\left(\frac{\sin \beta_{n} t-S_{n} \sin \omega_{n} t}{1-S_{n}^{2}}\right)-1 .
$$

As proved in [6], performing calculations for different values of $v t / l$, there exist upper-bound envelopes for the impact factors $n_{d}^{w}, n_{d}^{M}$ and $n_{d}^{T}$. The formulas are

1) for the maximum midpoint deflection of a single span, 


$$
\begin{gathered}
n_{d}^{w}=1.54 S_{1}, \quad S_{1}<0.5, \\
n_{d}^{w}=0.77, \quad S_{1} \geq 0.5 .
\end{gathered}
$$

2) for the maximum bending moment at the midpoint of a single span,

$$
\begin{gathered}
n_{d}^{M}=1.24 S_{1}, \quad S_{1}<0.36, \\
n_{d}^{M}=0.45, \quad S_{1} \geq 0.36 .
\end{gathered}
$$

3) the shear impact factor at a point near a support

$$
n_{d}^{T}=1.4 S_{1}
$$

The solutions obtained in the present paper are related to velocities lower than the critical velocity. The results of the analysis will be presented graphically for a numerical example, in Section 4.

\section{NUMERICAL EXAMPLES}

A numerical example has been calculated using Mathematica. Sample graphs obtained for a viscoelastic beam resting on a Kelvin-Voigt foundation will be presented. The following geometrical parameters and material characteristics were employed for the beam: beam density $\rho=2400 \mathrm{~kg} / \mathrm{m}^{3}$, cross-sectional dimensions $b \times h=0.25 \mathrm{~m} \times 0.47 \mathrm{~m}$, span length $l=7 \mathrm{~m}$, Young's modulus $E=30 \cdot 10^{3} \mathrm{MPa}$, coefficient of Winkler foundation $k=1.25 \mathrm{MN} / \mathrm{m}^{2}$, and damping number $\xi_{n}=5 \%$. The beam is subjected to a force $P=57.5 \mathrm{kN}$ moving at constant velocity $v=50 \mathrm{~m} / \mathrm{s}$. The position of the force is defined by the dimensionless coordinate $\eta=v t / l$. Thus, for $\eta \leq 1$ the moving force is located within the beam (forced vibration), while for $\eta>1$ the force has already left the beam (free vibrations).

Figure 1 shows the impact of damping on the dynamic deflection, bending moments and shear forces for the considered beam. In Figure 2 graphs of the dynamic factors for the midpoint deflection $\left(n_{d}^{w}\right)$ and for the midpoint bending moment $\left(n_{d}^{M}\right)$, as functions of the dimensionless parameter $S_{1}=\beta_{1} / \omega_{1}=\pi v /\left(l \omega_{1}\right)$, are presented. The graph of the shear dynamic amplification factor at a point near the support of the simply supported beam is shown in Figure 3. 
a)

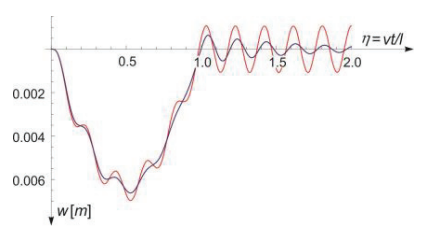

b)

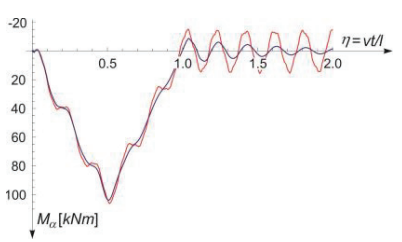

c)

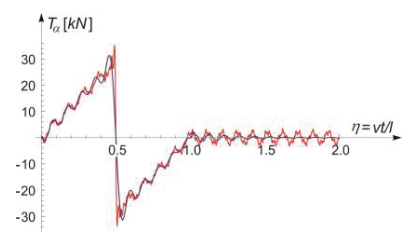

red line: damping not considered, blue line: damping considered

Fig. 1. Deflection, bending moment and shear force for the midpoint of a simply supported beam resting on a foundation and subjected to the moving force $v=50 \mathrm{~m} / \mathrm{s}:$ a) dynamic deflection, b) dynamic bending moment, c) dynamic shear force

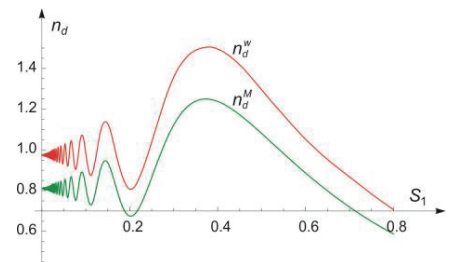

Fig. 2. Dynamic amplification factors for the midpoint of a simply supported beam depending on parameter

$$
S_{1}=\frac{\beta_{1}}{\omega_{1}}=\frac{\pi v}{l \omega_{1}} ; n_{d}^{w}: \text { deflection, } n_{d}^{M}: \text { bending moment }
$$

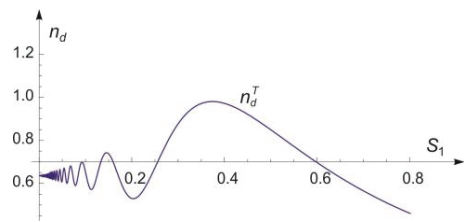

Fig. 3. Shear dynamic amplification factor at a point near the support of the simply supported beam

$$
\text { depending on parameter } S_{1}=\frac{\beta_{1}}{\omega_{1}}=\frac{\pi v}{l \omega_{1}}
$$

\section{CONCLUSIONS}

There are several definitions of the dynamic factor in the literature. In the present study, only two of these definitions were considered. It was shown that in the case of moving force, the dynamic factors strongly depend on the dimensionless speed parameter $S_{n}=\frac{\beta_{n}}{\omega_{n}}=\frac{n \pi v}{l \omega_{n}}$. If the parameter $S_{n}$, 
is equal to one, then a formula for the critical velocity of a moving load on the beam is obtained. For an elastic simply supported beam, this is

$$
S_{n}=1 \rightarrow v_{k r}=\frac{n \pi}{l} \sqrt{\frac{E J}{m}} .
$$

It should be noted that the dynamic factors are different for dynamic beam deflection, dynamic bending moment and dynamic shear force. The dynamic factors increase and decrease alternately depending on the load velocity or dimensionless parameter $S_{n}$. In the case of a single force on the beam, dynamic overloads are limited and do not exceed $60 \%$. In this case there is no resonance phenomenon.

\section{REFERENCES}

1. ASSHTO, „LRFD bridge design specifications”, American Association of State Highway and Transportation Officials, Washington, D.C., 1994.

2. S. Borowik, W. Szcześniak, „Drgania belki lepkosprężystej o skończonej długości i swobodnych końcach na podłożu sprężystym, wymuszone przesuwającą się siłą", Engineering Transactions, 4, 17, 1969, pp. 601-614.

3. C.H. Carey, E.J. O’Brien, A. González, „Dynamic amplification factors for bridges with various boundary conditions", Bridge \& Infrastructure Research in Ireland, Cork, Ireland, Institute of Technology, BCRI, 2010.

4. L. Deng, C.S. Cai, ,Development of dynamic impact factor for performance evaluation of existing multi-girder concrete bridges", Engineering Structures 32, 2010, pp. 21-31.

5. L. Frýba, Vibration of solids and structures under moving loads. Thomas Telford, 1999.

6. N.H. Galdos, D.R. Schelling, M.A. Sahin, „Methodology for impact factor of horizontally curved box bridges”, Journal of Structural Engineering, ASCE 119, No. 6, 1993, pp. 1917-1934.

7. S. Karaś, „Współczynniki dynamiczne obciążeń kolejowych w PN-EN 1991-2”, Drogownictwo 4, 2011, str.135-140.

8. M. Mensinger, R.R. Fard, A. Hacker, A. Nässl, „Validation of the dynamic amplification factor in case of historic railway steel bridges with short and medium spans", Procedia Engineering 156, 2011,pp. 233-240.

9. P. Paultre, O. Chaallal, J. Proulx, „Bridge dynamics and dynamic amplification factors - A review of analytical and experimental findings", Canadian Journal of Civil Engineering, 19, 1992, pp. 260-278.

10. PN-EN 1991-2 Eurokod 1: Oddziaływania na konstrukcje. Część 2: Obciążenia ruchome mostów, PKN, 2007.

11. J. Sadeghi, P. Barati, „Evaluation of conventional methods in analysis and design of railway track system”, International Journal of Civil Engineering Vol. 8, No. 1, 2010, pp. 44-56.

12. W. Szcześniak, M. Ataman, „Współczynniki dynamiczne w belkach poddanych ruchomym obciążeniom bezinercyjnym”, Księga Konferencyjna 14-go Seminarium Polsko-Ukraińskiego, OWPW, Warszawa 2006, str. 343-352.

13. B.J. Van Dyk, M.S. Dersch, J.R. Edwards, C.J. Ruppert, Ch.P.L. Barkan, „Evaluation of dynamic and impact wheel load factors and their application in design processes”, Journal of Rail and Rapid Transit, Vol. 231, 1, 2017, pp. 33-43.

14. Y.B. Yang, S.S. Liao, B.H. Lin, „Impact formulas for vehicles moving over a simple and continuous beams”, Journal of Structural Engineering, ASCE 121, No. 11, 1995, pp. 1644-1650.

15. Y.B. Yang, J.D. Yau, Y.S. Wu, „Vehicle-bridge interaction dynamics with applications to high-speed railways", World Scientific, Singapore 2004.

16. Q.L. Zhang, A. Vrouwenvelder, J. Wardenier, ,Dynamic amplification factors and EUDL, of bridges under random traffic flows", Engineering Structures 23, 2001, pp. 663-672.

17. H. Zobel, M. Mossakowski, R. Oleszek, „Normy krajowe dotyczące obciążeń kolejowych na przestrzeni dziejów”, Mosty kolejowe, Warszawa-Jachranka, OWPW 2013, str. 129-142. 


\section{LIST OF FIGURES AND TABLES:}

Fig. 1. Deflection, bending moment and shear force for the midpoint of a simply supported beam resting on a foundation and subjected to the moving force $v=50 \mathrm{~m} / \mathrm{s}:$ a) dynamic deflection, b) dynamic bending moment, c) dynamic shear force

Rys. 1. Wykresy w środku przęsła swobodnie podpartej belki spoczywającej na podłożu obciążonej ruchomą siłą, $v=50 \mathrm{~m} / \mathrm{s}:$ a) dynamiczne ugięcie, b) dynamiczny moment zginający, c) dynamiczna siła poprzeczna

Fig. 2. Dynamic amplification factors for the midpoint of a simply supported beam depending on parameter $S_{1}=\frac{\beta_{1}}{\omega_{1}}=\frac{\pi v}{l \omega_{1}} ; n_{d}^{w}$ : deflection, $n_{d}^{M}:$ bending moment

Rys. 2. Współczynniki dynamiczne $\mathrm{w}$ środku belki swobodnie podpartej $\mathrm{w}$ funkcji parametru $S_{1}=\frac{\beta_{1}}{\omega_{1}}=\frac{\pi v}{l \omega_{1}} ; n_{d}^{w}-$ ugięcie, $n_{d}^{M}-$ moment zginający

Fig. 3. Shear dynamic amplification factor at a point near the support of the simply supported beam depending on parameter $S_{1}=\frac{\beta_{1}}{\omega_{1}}=\frac{\pi v}{l \omega_{1}}$

Rys. 3. Współczynnik dynamiczny siły poprzecznej tuż przy podporze belki swobodnie podpartej w funkcji parametru $S_{1}=\frac{\beta_{1}}{\omega_{1}}=\frac{\pi v}{l \omega_{1}}$ 


\section{WSPÓlCZYNNIKI DYNAMiczne w PRZYPADKu RuCHOMYCH ObCiĄżEŃ - ANALIZA TEORETYCZNA}

Słowa kluczowe: drgania belek, podłoże lepko-sprężyste, obciążenie ruchome, tłumienie, współczynniki dynamiczne

\section{STRESZCZENIE}

Jednym z czynników mających wpływ na drgania belek i płyt w konstrukcjach mostowych i drogowych jest prędkość pojazdów. Ponieważ w praktyce inżynierskiej często konstrukcje projektuje się wykorzystując rozwiązania statyki i stosując współczynniki dynamiczne, właściwe ich określenie ma duże znaczenie. Wpływ na wartości współczynników dynamicznych, oprócz prędkości pojazdów, ma szereg czynników, np. rozpiętość i sposób podparcia przęsła, stan konstrukcji, nierówności nawierzchni i inne, co było przedmiotem analizy wielu badaczy, m.in. w pracach $[3,4,8,12$, 14]. Przegląd analitycznych i eksperymentalnych metod wyznaczania współczynników dynamicznych w mostach drogowych znaleźć można w opracowaniu [9].

Pojęcie współczynnika dynamicznego pojawiło się w drugiej połowie dziewiętnastego wieku przy projektowaniu mostów kolejowych. Większość norm dotyczących projektowania konstrukcji inżynierskich poddanych działaniu obciążeń ruchomych do dnia dzisiejszego wprowadza ten współczynnik. W zaleceniach AASHTO [1] współczynnik dynamiczny zależy od rozpiętości przęsła mostu (wzór (1.1)). Z kolei w europejskich normach ([10]) współczynnik dynamiczny w mostach kolejowych zależy dodatkowo od jakości utrzymania toru (wzory (1.2)).

Normy obowiązujące w Polsce i wprowadzone tam współczynniki dynamiczne w mostach omówiono m.in. w pracach [7] i [17]. W opracowaniu [11] przedstawiony został szereg wzorów na współczynniki dynamiczne zaproponowane przez różnych badaczy i organizacje techniczne.

Wśród prac naukowych poświęconych temu zagadnieniu należy wymienić również monografię Fryby [5], monografię Yanga i innych [15] i jego pracę [14], prace Galdosa [6], Paultera [9], Zhanga [16] oraz inne.

W bogatej literaturze przedmiotu można znaleźć różne definicje współczynnika dynamicznego. Przeważnie współczynnik ten definiowany jest na dwa sposoby, (wzory (1.3)).

W niniejszej pracy przeanalizowany został wpływ prędkości pojazdów na wielkość współczynników dynamicznych, określonych wzorami (1.3), przy założeniu, że nawierzchnia jest bez nierówności.

Wpływ ruchomego obciążenia na drgania nawierzchni drogowej i kolejowej oraz mostów drogowych i kolejowych przedstawiono rozwiązując zadanie belki swobodnie podpartej spoczywającej na podłożu odkształcalnym, obciążonej siłą poruszającą się ze stałą prędkością. Wyznaczono współczynniki dynamiczne, które są różne w przypadku ugięć, momentów zginających i sił poprzecznych (wzory (3.1) - (3.3)). W analizie uwzględniono zarówno drgania wymuszone jak również drgania swobodne, kiedy obciążenie jest już poza belką. Położenie siły opisane jest bezwymiarową współrzędną $\eta=v t / l$. Zatem przy $\eta \leq 1$ ruchoma siła znajduje się na przęśle (drgania wymuszone), zaś przy $\eta>1$ siła jest już poza belką (drgania swobodne). Przytoczono z monografii [6] wzory uogólniające, określające górne granice współczynników dynamicznych, uzyskane na podstawie obliczeń przeprowadzonych przy różnych wartościach parametru opisującego położenie ruchomej siły $v t / l$. W przypadku współczynnika dynamicznego maksymalnego ugięcia i momentu zginającego środka pojedynczego przęsła są to odpowiednio wzory (3.4) i (3.5). Z kolei współczynnik dynamiczny siły poprzecznej tuż przy podporze dany jest wzorem (3.6).

W przykładzie obliczeniowym, wykonanym przy pomocy pakietu Mathematica, przedstawiono przykładowe wykresy uzyskane dla belki lepko-sprężystej spoczywającej na podłożu Winklera. Na rysunku 1 pokazano wpływ thumienia na dynamiczne ugięcia, momenty zginające i siły poprzeczne w rozważanej belce. Rysunek 2 przedstawia wykres 
współczynnika dynamicznego dla ugięcia i momentu zginającego w środku rozpiętości belki w funkcji bezwymiarowego parametru $S_{1}=\beta_{1} / \omega_{1}=\pi v /\left(l \omega_{1}\right)$. Wykres współczynnika dynamicznego siły poprzecznej, wyznaczony w punkcie na podporze belki swobodnie podpartej, znajduje się na rysunku 3.

W literaturze przedmiotu istnieje kilka definicji współczynnika dynamicznego. W opracowaniu rozważania ograniczono do dwóch. Z analizy wynika, że współczynniki dynamiczne zależą silnie w przypadku ruchomych obciążeń od bezwymiarowego parametru prędkości $S_{n}=\frac{\beta_{n}}{\omega_{n}}=\frac{n \pi v}{l \omega_{n}}$. Parametr $S_{n} \mathrm{w}$ przypadku kiedy równa się jedynce prowadzi do wzoru na prędkość krytyczną ruchomego obciążenia na belce. Prędkość krytyczna ruchomej siły na sprężystej belce swobodnie podpartej określona jest wzorem:

$$
S_{n}=1 \rightarrow v_{k r}=\frac{n \pi}{l} \sqrt{\frac{E J}{m}} .
$$

W pracy pokazano, że współczynniki dynamiczne są różne w przypadku dynamicznego ugięcia belki, w przypadku dynamicznego momentu zginającego oraz w przypadku dynamicznej siły poprzecznej. Współczynniki te rosną i maleją naprzemiennie w funkcji prędkości albo bezwymiarowego parametru $S_{n}$. Przeciążenia dynamiczne są ograniczone w przypadku pojedynczej siły skupionej na belce i nie przekraczają $60 \%$. Od pojedynczej siły ruchomej nie ma zjawiska rezonansu na belce. 